\title{
Validation of an instrument to assess health care quality (FACIT-TS-PS) in cancer patients
}

\author{
Jazmín E. Hernández-Marín, ${ }^{1}$ Oscar Galindo-Vázquez, ${ }^{2 *}$ Rosario Costas-Muñíz, ${ }^{3}$ \\ Paula Cabrera-Galeana, ${ }^{4}$ M. del Rosario Caballero-Tinoco, ${ }^{5}$ José L. Aguilar-Ponce ${ }^{6}$ and Abel Lerma ${ }^{7}$ \\ ${ }^{1}$ Faculty of Psychology, Universidad Nacional Autónoma de México; ${ }^{2}$ Psycho-oncology Department, Instituto Nacional de Cancerología; ${ }^{3}$ Department \\ of Psychiatry and Behavioral Sciences, Memorial Sloan-Kettering Cancer Center, New York, United States of America; ${ }^{4}$ Medical Oncology Department \\ Head Office, Instituto Nacional de Cancerología; ${ }^{5}$ Nursing Department, Instituto Nacional de Cancerología; ${ }^{6}$ Medical Oncology Department, Instituto \\ Nacional de Cancerología; 'Institute of Health Sciences, Universidad Autónoma del Estado de Hidalgo, Hidalgo, Mexico. ${ }^{1,2,4,5,6}$ Mexico City, Mexico
}

\begin{abstract}
Introduction: Cancer patient satisfaction with the healthcare team is of great relevance for assessing the quality of the care provided by the health system. In Mexico, no valid and reliable tool is available to assess this construct. Objective: To validate the Functional Assessment of Chronic Illness Therapy-Treatment Satisfaction-Patient Satisfaction (FACIT-TS-PS) instrument, version 4, in cancer patients. Method: Cross-sectional design, non-probability convenience sampling. The sample consisted of 200 cancer-diagnosed patients, with mean age of $45.86 \pm 15.01$ years. Exploratory and confirmatory factor analyses were conducted. Results: The exploratory factor analysis identified four factors, with a Cronbach alpha of 0.945 , and an explained variance of $68.15 \%$. The confirmatory factor analysis indicated that the proposed theoretical model adjusts to the data with an error close to zero and, in addition, it is balanced and carefully measures overall patient satisfaction with the treatment. Conclusion: FACIT-TS-PS was shown to be a valid and reliable instrument for use in clinical care and research in Mexican cancer patients. Its use is recommended in the evaluation of oncology multidisciplinary healthcare teams in Mexico.
\end{abstract}

KEY WORDS: Cancer. Satisfaction with the health care team. Validation of an instrument. Mexican population.

\section{Validación de FACIT-TS-PS en una muestra de pacientes mexicanos con cáncer}

\section{Resumen}

Introducción: La satisfacción del paciente oncológico con el equipo de salud es de relevancia para evaluar la calidad de la atención del sistema de salud. En México no se dispone de una herramienta válida y confiable para evaluar este constructo. Objetivo: Validar el Instrumento de Evaluación de Funcionalidad en el Tratamiento para Enfermedades Crónicas-Satisfacción con el Tratamiento-Satisfacción del Paciente (FACIT-TS-PS) versión 4, en pacientes mexicanos con cáncer. Método: Diseño transversal, muestreo no probabilístico, por disponibilidad. La muestra consistió en 200 pacientes diagnosticados con cáncer, con edad promedio de $45.86 \pm 15.01$ años. Se realizó un análisis factorial exploratorio y confirmatorio. Resultados: Se identificaron cuatro factores con un alfa de Cronbach de 0.945 y una varianza explicada de $68.15 \%$. El análisis factorial confirmatorio indicó que el modelo teórico propuesto se ajusta a los datos con error próximo a cero y que, además, es equilibrado y mide cuidadosamente la satisfacción global del paciente con el tratamiento. Conclusión: FACIT-TS-PS mostró ser un instrumento válido y confiable para su uso en la atención clínica e investigación dirigida a pacientes mexicanos con cáncer. Se recomienda su utilización en la evaluación de equipos de salud multidisciplinarios en oncología en México.

PALABRAS CLAVE: Cáncer. Satisfacción con el equipo de salud. Validación de un instrumento. Población mexicana.

Correspondence:

*Oscar Galindo-Vázquez

E-mail: psigalindo@yahoo.com.mx
Gac Med Mex. 2020;156:397-404

Contents available at PubMed

www.gacetamedicademexico.com

0016-3813/@ 2020 Academia Nacional de Medicina de México, A.C.. Published by Permanyer. This is an open access article under the CC BY-NC-ND license (http://creativecommons.org/licenses/by-nc-nd/4.0/). 


\section{Introduction}

Patient satisfaction with medical care is a multidimensional variable in which the individual evaluates different aspects of medical care. ${ }^{1}$ It includes concerns about disease and its treatment, financial burden, communication with the health team, access to services, satisfaction with treatment explanations, and trust in the physician. ${ }^{2}$ It is particularly relevant in the field of cancer care, which is characterized by a considerable number of medical consultations, long hospital stays and a variety of treatments. The satisfaction generated by interpersonal aspects in the interaction with the medical or nursing staff determines, to a large extent, overall satisfaction of the cancer patient with the medical care process ${ }^{3-9}$ and has an impact on treatment adherence,,$^{10,11}$ psychological aterations, ${ }^{12}$ quality of life, ${ }^{13,14}$ and even on longer survival. ${ }^{11}$

Patient satisfaction is considered to be relevant in at least four areas: comparison of health systems or programs, health services quality assessment, identification of aspects of services that need modifications and assistance to social organizations in the identification of consumers with low acceptability of services. ${ }^{15}$ Satisfaction evaluation becomes a permanent and dynamic task that provides data on how it is doing and what is missing to meet patient expectations. It not only allows obtaining an indicator of excellence, it is rather an instrument for excellence ${ }^{16}$.

For the Mexican health sector, it is essential to have an instrument that provides valid and reliable information regarding the evaluation of the healthcare process carried out by the patient. In this context, some of the instruments that have been used to measure patient satisfaction with medical care are: CASE-cancer, ${ }^{17}$ ChPSQ-9 ${ }_{18}^{18}$ EORTC IN-PATSAT32 ${ }^{19}$ and PSCC ${ }^{20}$. These instruments exhibit a considerable variability of constructs, with most of them assessing the patient satisfaction with the doctor, and with several important members from the health team being omitted. In the literature review, no scale was found that assessed patient satisfaction with the health team in cancer patients and that was validated for the Mexican population.

Therefore, the purpose of this study was to validate the Functional Assessment of Chronic Diseases Therapy-Treatment Satisfaction-Patient Satisfaction (FACIT-TS-PS), version 4, which is able to assess patient satisfaction, focusing on the trust and clarity of communication with three of the main groups of medical oncology care: medical staff, nursing staff and personnel in charge of treatment (technical assistants, clinical laboratory technicians).

\section{Method}

Authorization was requested from the FACIT.org organization to validate the instrument in Mexico. The research was approved by the Ethics Committee and the Research Committee of the National Institute of Cancer of Mexico City.

Participants were obtained by availability at the $\mathrm{Na}$ tional Institute of Cancer outpatient services between October 2018 and December 2018. The participants agreed to participate after having understood and signed an informed consent document. Participation criteria were the following:

- Inclusion criteria: diagnosis of any type of cancer, on any type of treatment or follow-up period, and possession of literacy skills.

- Exclusion criteria: cognitive impairment that prevented the subjects from answering the surveys, or severe visual or hearing impairment.

- Elimination Criteria: failure to completely answer the instrument and incorrect filling of the questionnaires.

The FACITS-TS-PS instrument and a format to evaluate criteria on relevance, writing, appropriate language for the population, theoretical validity, apparent validity and content validity were sent to 15 experts who are members of oncology multidisciplinary teams. Subsequently, modifications were made in order to improve instructions and items understanding.

Adaptation to Spanish in the Mexican population was carried out through a pilot test in 29 patients. A case record form was applied according to the guidelines indicated by Mora et al., which included a specific questionnaire on the understanding of instructions, each item, and answer options ${ }^{21}$.

A participant identification card was designed, which included sociodemographic and clinical data. The FACIT-TS-PS, version 4, developed by Peipert et al, ${ }^{2}$ was used. This instrument is a self-administered Likert-type scale that allows assessing patient satisfaction with the health care team, made up of 26 items distributed in five factors: medical communication (alpha $=0.95)$, communication with the treating staff (alpha $=0.89$ ), technical competence (alpha $=0.86$ ), communication with the nursing staff (alpha $=0.72$ ), and confidentiality and trust (alpha $=0.93$ ), as well as 
three individual items that are not included in the final summation. Total items were 29.

Data were analyzed using the SPSS statistical package, version 21. A factor analysis of the main components with varimax rotation was used, with the criteria for the factor analysis being the following: without suppressing small coefficients, without taking a minimum number of items per factor and with internal consistency coefficients for each Cronbach alpha factor $\geq 0.60$.

Fitting of the model to four factors was evaluated through a confirmatory factor analysis, where the maximum likelihood method was used, which included the following steps: ${ }^{22-24}$ identification and specification of the model, estimation of standardized parameters, $\left(R^{2}\right.$ correlations, covariances, modification rates and critical proportions of differences), and finally, fitting evaluation by observing estimators acceptable limits, as well as non-collinearity in the measured variables. The following indices were estimated: $\chi^{2}, \chi^{2} /$ degrees of freedom ratio, goodness of fit index (GFI) and their complements: the Tucker-Lewis Index (TLI) and the adjusted goodness of fit index (AGFI), as well as the comparative fit index (CFI), ${ }^{25}$ which is the best indicator for samples equal to or greater than 200, and the root mean square error of approximation (RMSEA).

\section{Results}

A non-probabilistic sample of 200 cancer-diagnosed patients of both genders, with an average of $45.86 \pm$ 15.01 years, who attended the National Institute of Cancer for consultation, was studied (Table 1).

The Kaiser-Meyer-Olkin test value was 0.91 $(p=0.001)$, which confirmed that the sample was adequate for the analysis. An exploratory factor analysis using the main components method and varimax rotation with 26 items yielded a model with four factors.

Items "Did you trust the treatment suggestions of your doctor(s)?" (TS37) and "Did you trust your doctor(s)?" (TS36) of the Trust and confidentiality factor were moved to the Medical knowledge and skills factor; as well as item "Did the staff in charge of your treatment respect your privacy?" (TS35) was moved to the "Communication with the nursing staff" factor. Items "Did you feel that the staff in charge of your treatment answered your questions honestly?" (TS34) and "Did your doctor(s) explain to you the possible benefits of your treatment?" (TS10) were removed because they had a factor load above 0.40 in more than one factor.
In the reliability analysis, a total Cronbach alpha of 0.94 was obtained and 24 items grouped into four factors that explain $68.15 \%$ of variance. The Trust and confidentiality factor was merged with the medical knowledge and skills factor, and naming this new factor medical knowledge and trust was therefore decided (Table 2).

The comparative goodness of fit relative indices (CFI, TLI and AGFI) were very close to the ideal value (equal to, close to or higher than 0.95 , respectively), confirming that the model is acceptable in comparison with the null model. The CFI value, which tended to 1 (higher than 0.5) indicates a more efficient model than the null mode ${ }^{26}$.

Root mean square residual (RMR) index proximity to zero, and its value being lower than 0.08 $(R M R=0.044)$, ratify the virtually non-existing difference between the matrix of observed and predicted covariance; therefore it can be assumed that the discrepancy between the proposed model and the real data is almost nil or very low ${ }^{24}$.

In general, the chi-square value adjusted to 244 degrees of freedom was 2.431 (ideally, it should be $<3$ ), with a $p$-value $<0.05$, which confirms an absolute fit of observed data to the model ${ }^{24}$.

A value close to zero was observed for the RMSEA index $(0.085)$ and the superior interval was very close to $0.08(0.076-0.093)$, indicating almost nullity in the model error. ${ }^{24}$

In the Hoelter test ( $n=101, p=0.01)$, the theoretical sample size exceeded the used sample size, and thus it could be claimed that the model was correct and the hypothesis (probability of an alpha error of 0.01 ) that the sample was sufficient for the analyses was accepted. Table 3 and figure 1 of the final model summarize these results.

\section{Discussion}

The evaluation of cancer patient satisfaction with the health team is of great relevance due to its relationship with patient therapeutic continuity, to the results on patient health and different psychological effects. The FACIT-TS-PS instrument showed an exploratory structure similar to that of the original version, as well as adequate psychometric properties. The confirmatory factor analysis indicated that the proposed theoretical model fitted almost perfectly to the data of the used sample, and the structural indicators of the model (CFI, RMR and RMSEA) suggest that it is a model with an error close to zero, balanced, 
Table 1. Sociodemographic and clinical characteristics of a sample of 200 patients diagnosed with cancer

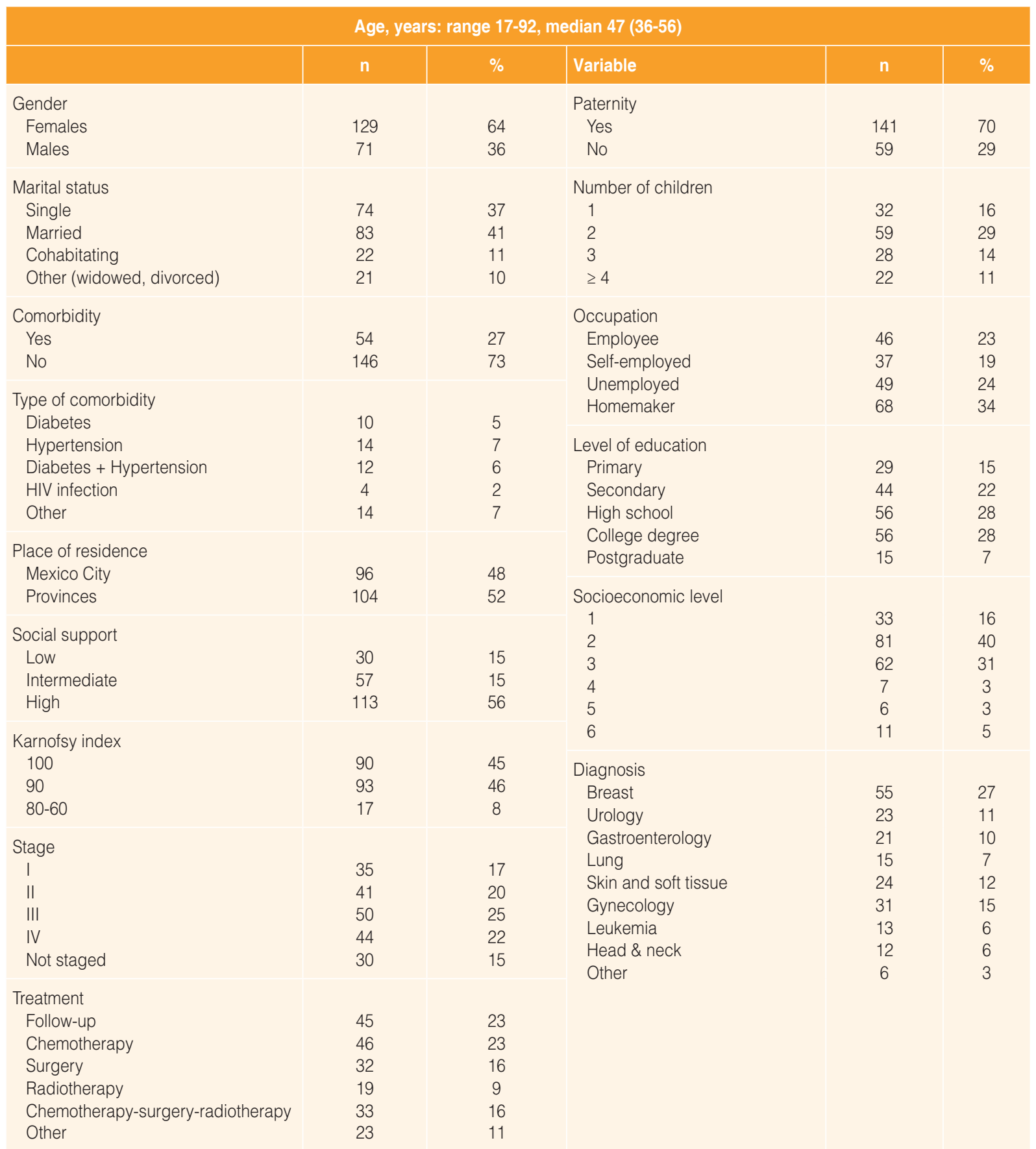

and that it carefully measures overall patient satisfaction with the health team.

The trust and confidentiality factor assesses general trust of the patient with the health team. By unifying the items of this factor with those of medical knowledge and skills, trust in general with the health team was identified to mostly rely in the perception of the experience of the medical team in the treatment, which could be explained according to what Wright indicates, who refers that trust in the experience of doctors is cancer patients' main concern. Being a doctor was enough, but trust increased when doctors showed efficiency and technical skills; ${ }^{9}$ patients even state that they trust the medical profession as the system's main agent. This trust is higher than that placed in other health professions, and it is 
Table 2. FACIT-TS-PS scale version 4 exploratory factor analysis in cancer patients $(n=200)$

\begin{tabular}{|c|c|c|c|c|c|c|}
\hline $\begin{array}{l}\text { Total Cronbach alpha }=0.94 \\
\text { Total explained variance }=68.15 \%\end{array}$ & \multicolumn{4}{|c|}{ Factor load } & Item & $\begin{array}{c}\text { Item } \\
\sigma\end{array}$ \\
\hline \multicolumn{7}{|l|}{ Factor 1. Communication with the doctor } \\
\hline TS16. Did your doctor(s) seem to understand your needs? & 0.81 & 0.27 & 0.09 & 0.17 & 2.44 & 0.81 \\
\hline TS13. Did you get the chance to say what was important to you? & 0.80 & 0.11 & 0.16 & 0.19 & 2.38 & 0.911 \\
\hline TS15. Did your doctor(s) show a real interest in you? & 0.75 & 0.31 & 0.09 & 0.19 & 2.53 & 0.78 \\
\hline TS18. Were you able to speak to your doctor(s) when you needed? & 0.74 & 0.18 & 0.20 & 0.18 & 2.26 & 0.97 \\
\hline TS27. Were you motivated to participate in decision-making regarding your health care? & 0.73 & 0.27 & 0.14 & 0.21 & 2.27 & 1.02 \\
\hline TS30. Did your doctor(s) seem to respect your opinions? & 0.68 & 0.29 & 0.26 & 0.25 & 2.52 & 0.80 \\
\hline TS14. Did your doctor(s) seem to understand what was important to you? & 0.68 & 0.28 & 0.24 & 0.22 & 2.40 & 0.87 \\
\hline TS12. Did you get the chance to ask questions? & 0.66 & 0.26 & 0.09 & 0.15 & 2.55 & 0.75 \\
\hline TS28. Did you have enough time to make decisions about your health care? & 0.65 & 0.26 & 0.26 & 0.13 & 2.29 & 0.95 \\
\hline TS9. Were you able to understand the explanations of your doctor(s)? & 0.58 & 0.18 & 0 & 0.10 & 2.38 & 0.77 \\
\hline TS11. Did your doctor(s) explain the possible side effects or risks of your treatment? & 0.41 & 0.38 & 0.07 & 0.34 & 2.44 & 0.86 \\
\hline \multicolumn{7}{|l|}{ Factor 2. Medical knowledge and trust } \\
\hline TS23. Did your doctor(s) seem to have experience in the treatment of your disease? & 0.27 & 0.76 & 0.06 & 0.21 & 2.82 & 0.51 \\
\hline TS37. Did you trust the treatment suggestions of your doctor(s)? & 0.30 & 0.75 & 0.21 & 0.03 & 2.77 & 0.52 \\
\hline TS25. Did your doctor(s) assess your case and offer detailed treatment? & 0.32 & 0.74 & 0.20 & 0.19 & 2.68 & 0.67 \\
\hline $\begin{array}{l}\text { TS24. Did you feel your doctor(s) were aware of the latest medical developments on } \\
\text { your condition? }\end{array}$ & 0.27 & 0.69 & 0.09 & 0.25 & 2.70 & 0.65 \\
\hline TS36. Did you trust your doctor(s)? & 0.35 & 0.67 & 0.15 & 0.17 & 2.73 & 0.60 \\
\hline \multicolumn{7}{|c|}{ Factor 3. Communication with the nursing staff } \\
\hline TS32. Did the nursing staff show a real interest in you? & 0.11 & 0.07 & 0.86 & 0.20 & 2.60 & 0.70 \\
\hline TS33. Did the nursing staff seem to understand your needs? & 0.16 & 0.05 & 0.85 & 0.25 & 2.50 & 0.79 \\
\hline TS31. Were you able to understand the nursing staff's explanations? & 0.13 & 0.18 & 0.81 & 0.11 & 2.60 & 0.68 \\
\hline TS35. Did the staff in charge of your treatment respect your privacy? & 0.28 & 0.32 & 0.62 & 0.02 & 2.74 & 0.55 \\
\hline \multicolumn{7}{|c|}{ Factor 4. Communication with the treating staff } \\
\hline $\begin{array}{l}\text { TS21. Did the staff in charge of your treatment explain to you how your health and the } \\
\text { treatment might affect your personal relationships (family, friends, work)? }\end{array}$ & 0.24 & 0.11 & 0.15 & 0.85 & 1.83 & 1.20 \\
\hline $\begin{array}{l}\text { TS20. Did the staff in charge of your treatment explain to you how your health and } \\
\text { treatment might affect your usual daily activities (e.g., bathing, dressing)? }\end{array}$ & 0.18 & 0.22 & 0.24 & 0.80 & 2.12 & 1.13 \\
\hline $\begin{array}{l}\text { TS22. Did the staff in charge of your treatment explain to you how your health and the } \\
\text { treatment might affect you emotionally? }\end{array}$ & 0.26 & 0.12 & 0.07 & 0.78 & 1.9 & 1.2 \\
\hline $\begin{array}{l}\text { TS19. Did the staff in charge of your treatment explain to you how your health and the } \\
\text { treatment might affect your regular work (including household chores)? }\end{array}$ & 0.26 & 0.34 & 0.28 & 0.67 & 2.18 & 1.09 \\
\hline $\begin{array}{l}\text { Total Cronbach alpha }=0.94 \\
\text { Total explained variance }=68.15 \%\end{array}$ & \multicolumn{4}{|c|}{ Factor load } & $\overline{\bar{X}}$ & $\begin{array}{l}\text { Item } \\
\sigma\end{array}$ \\
\hline Factor alpha value & 0.93 & 0.88 & 0.86 & 0.88 & & \\
\hline Percentage of explained variance & 25.83 & 15.70 & 13.51 & 13.09 & & \\
\hline Mean & 26.43 & 13.70 & 10.43 & 8.01 & & \\
\hline Standard deviation & 7.42 & 2.49 & 2.31 & 4.00 & & \\
\hline Factor variance & 55.13 & 6.22 & 5.35 & 16.06 & & \\
\hline Factor intra-class correlation & 0.56 & 0.60 & 0.61 & 0.66 & & \\
\hline Lower value & 0.50 & 0.55 & 0.55 & 0.60 & & \\
\hline Upper value & 0.61 & 0.66 & 0.68 & 0.71 & & \\
\hline F-value & 15.01 & 8.80 & 7.50 & 8.88 & & \\
\hline$p$-value & $\leq 0.001$ & $\leq 0.001$ & $\leq 0.001$ & $\leq 0.001$ & & \\
\hline
\end{tabular}


Table 3. Goodness of fit indices of the confirmatory model resulting from the FACIT-TS-PS scale (satisfaction with the health team), 4 factors in patients with cancer $(n=200)$

\begin{tabular}{|c|c|c|c|}
\hline Statistical parameter & Desirable criterion & Value in this study & Interpretation \\
\hline $\begin{array}{l}\chi^{2} / \text { degrees of freedom ratio } \\
\text { absolute fit }\end{array}$ & $<2$ or 3 & $595,772 / 244 \mathrm{df}=2.441$ & $\begin{array}{l}\text { Model errors are null with the used sample } \\
\text { and absolute fit is excellent }\end{array}$ \\
\hline Goodness of fit index (GFI) & $\begin{array}{l}>0.90 \\
\text { Preferably }>0.95\end{array}$ & $\mathrm{GFI}=0.809$ & Acceptable fit \\
\hline $\begin{array}{l}\text { Comparative goodness of fit index } \\
\text { (CFI) }\end{array}$ & $\begin{array}{l}>0.90 \\
\text { Preferably }>0.95\end{array}$ & $\mathrm{CFI}=0.900$ & Very acceptable comparative fit \\
\hline Root mean square residual (RMR) & Close to zero & $\mathrm{RMR}=0.044$ & $\begin{array}{l}\text { Model error close to zero, almost perfect fit } \\
\text { of the model to the data }\end{array}$ \\
\hline $\begin{array}{l}\text { Root mean square error of } \\
\text { approximation (RMSEA) }\end{array}$ & $<0.08$, close to zero & $\begin{array}{l}\text { RMSEA }=0.085 \\
(0.076-0.093)\end{array}$ & $\begin{array}{l}\text { Model error close to zero, almost perfect fit } \\
\text { of the model to the data }\end{array}$ \\
\hline
\end{tabular}

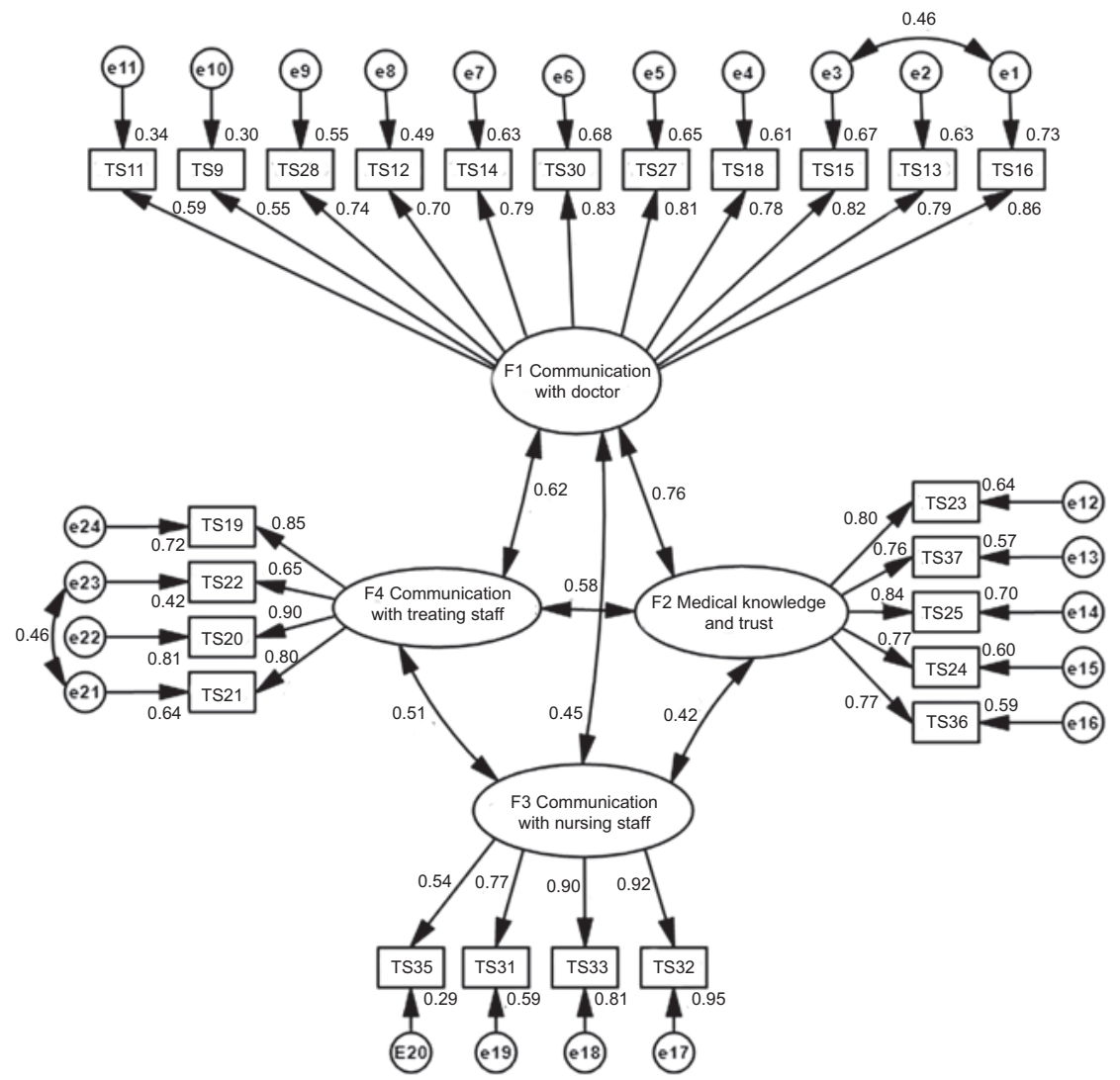

Figure 1. FACIT TS-PS version 4 four-factor first-order confirmatory factor analysis model. $\chi^{2}=595.772,244 \mathrm{df}, \chi^{2} / \mathrm{degrees}$ of freedom index $=2.431, p=0.000$, comparative goodness of fit index $=0.900$, Tucker-Lewis index $=0.887$, adjusted goodness of fit index $=0.766$, root mean square residual $=0.044$, root mean square error of approximation $=0.085(0.076-0.093)$, Hoelter test, $n=101,(p=0.01)$.

maintained despite complaints about the health care received $^{3}$. In the same sense, Navarro refers that patients give more importance to doctor's competence, information on the disease and treatments, than to aspects related to emotional and contextual support ${ }^{27}$.

According to the sample obtained in this research, $40 \%$ of participants were at socioeconomic level 2 , 
i.e., low. Lower-income populations have been found to have lower levels of satisfaction, especially those who attend public hospitals ${ }^{28}$. Among the participants, $27 \%$ had some other comorbidity in addition to cancer, which is why medical attention must focus on caring for and understanding the physical and psychological conditions resulting from the interaction of cancer with different chronic diseases, such as diabetes and hypertension. Therefore, knowing the satisfaction of the cancer patient in settings of the public health sector in Mexico is of high relevance.

FACIT-TS-PS advantage over other satisfaction instruments is that, beyond knowing the amount of information communicated to the patient, it focuses on knowing the clarity of communication with the medical staff, integrating the nursing staff and the staff in charge of treatment, which constantly interact in the care of cancer patients. Effective communication exerts a positive influence not only on patient emotional health but also on the resolution of physical symptoms, functional and physiological status, and adaptation to the disease ${ }^{7}$. Therefore, the satisfaction evaluation provided by FACIT-TS-PS could be used at different medical oncology care departments of the country, with advantages in comparison with other studies carried out in Mexico on patient satisfaction, which include the following:

- It uses a valid and reliable scale to know the satisfaction with the health team.

- It was validated in an cancer population.

- It focuses on knowing the quality of communication with three of the main medical care sectors.

- Aspects of communication related to the information provided on the expected psychological and social impact of the disease are considered; in addition, it can serve as an outcome measure of the quality of medical care or treatment. ${ }^{13,14}$

Some of the limitations of this research include a lack of external validity through correlations with concurrent measures. Finally, FACIT-TS-PS is expected to be used in the Mexican clinical population. It is recommended that future studies should evaluate the stability of the instrument over time, and for investigations to be developed where the impact of patient satisfaction with the health team can be analyzed using other types of constructs such as treatment adherence and acceptability, quality of life, and anxiety or depressive symptoms.

\section{Conflict of interests}

The authors declare that they have no conflicts of interest.

\section{Funding}

The authors did not receive any sponsoring to carry out this article.

\section{Ethical disclosures}

Protection of human and animal subjects The authors declare that the procedures followed adhered to the ethical standards of the responsible human experimentation committee and were in agreement with the World Medical Association and the Declaration of Helsinki.

Confidentiality of data The authors declare that they have followed the protocols of their work center on the publication of patient data.

Right to privacy and informed consent The authors declare that no patient data appear in this article.

\section{References}

1. Linder-Pelz S, Struening E. The multidimensionality of patient satisfaction with a clinic visit. J Community Health. 1985;10:42-54

2. Peipert J, Beaumont J, Bode R, Cella D, Garcia S, Hahn E. Development and validation of the functional assessment of chronic illness therapy treatment satisfaction (FACIT TS) measures. Qual Lifi Res. 2013;23:815-824

3. Joey A. J. El paciente del siglo XXI. Anales Sis San Navarra. 2006:29:85-90.

4. Kleeberg U, Tews J, Ruprecht T, Höing M, Kuhlmann A, Runge C. Patient satisfaction and quality of life in cancer outpatients: results of the PASQOC study. Supportive Care in Cancer. 2005;13:303-310.

5. Lis CG, Rodeghier M, Gupta D. Distribution and determinants of patient satisfaction in oncology: a review of the literature. Patient Prefer Adherence. 2009:287-304.

6. Macleod CJ. Verbal communication in nursing. In: Faulkner A (editor). Communication. Scotland: Churchill Livingstone; 1984

7. Travado L, Grassi L, Gil F, Ventura C, Martins C. La comunicación tigma-paciente en los oncólogos del sur de Europa: la influencia de la orientación psicosocial y el agotamiento. Rev Toxicomanias. 2005; 44:15-24.

8. von Gruenigen VE, Hutchins JR, Reidy AM, Gibbons HE, Daly BJ, Eldermire EM, et al. Gynecologic oncology patients' satisfaction and symptom severity during palliative chemotherapy. Health Qual Life Outcomes. 2006;4:84.

9. Wright EB, Holcombe C, Salmon P. Doctors' communication of trust, care, and respect in breast cancer: qualitative study. BMJ. 2004;328:864.

10. Bui QUT, Ostir GV, Kuo YF, Freeman J, Goodwin JS. Relationship of depression to patient satisfaction: findings from the barriers to breast cancer study. Breast Cancer Res Treat. 2005:89:23.

11. Gupta D, Rodeghier M, Lis CG. Patient satisfaction with service quality in an oncology setting: implications for prognosis in non-small cell lung cancer. Int J Qual Health Care. 2013;25:696-703.

12. Wyshak G, Barsky AJ. Satisfacción y eficacia de la atención médica en relación con la ansiedad y la tigmaion. Gen Hosp Psychiatry. 1995;17:108-114.

13. Pascoe GC. Patient satisfaction in primary health care: a literature review and analysis. Eval Program Plann. 1983:6:185-210.

14. Locker D, Dunt D. Theoretical and methodological issues in sociological studies of consumer satisfaction with medical care. Soc Sci Med. 1978;12:283-292.

15. Seclén PJ, Darras C. Satisfacción de usuarios de los servicios de salud: factores sociodemográficos y de accesibilidad asociados: Perú, 2000. An Fac Med. 2005:66:127-141.

16. Massip-Pérez C, Ortiz-Reyes R, Llantá-Abreu M, Peña-Fortes M, Infante-Ochoa I. La evaluación de la satisfacción en salud: un reto a la calidad. Rev Cubana Salud Publica. 2008:34:1-10.

17. Wolf, M. S., Chang, C. H., Davis, T., Makoul, G. Development and validation of the Communication and Attitudinal Self-Efficacy scale for cancer (CASE-cancer). Patient Education and Counseling. 2005;57(3), 333-341. 
18. Wong WS, Fielding R, Wong CM, Hedley AJ. Psychometric properties of the Nineditem Chinese Patient Satisfaction Questionnaire (ChPSQ $\square$ ) in Chinese patients with hepatocellular carcinoma. Psychooncology. 2008;17:292-299.

19. Brédart A, Bottomley A, Blazeby JM, Conroy T, Coens C, D'Haese S, et al. An international prospective study of the EORTC cancer in-patient satisfaction with care measure (EORTC IN-PATSAT32). Eur J Cancer. 2005;41:2120-2131

20. Jean-Pierre P, Fiscella K., Freund KM, Clark J, Darnell J, Holden A, et al. Structural and reliability analysis of a patient satisfaction with cancer-related care measure: A multisite patient navigation research program study. Cancer. 2011;117:854-861.

21. Mora RJ, Bautista AN, Natera G, Pedersen D. Adaptación cultural de instrumentos de medida sobre tigma y enfermedad mental en la Ciudad de México. Salud Mental. 2013;36:9-18

22. Kline R. Principles and practice of structural equation modeling. USA: Guilford; 2005
23. George D, Mallery P. Using SPSS for Windows step by step: a simple guide and reference. USA: University of Michigan; 2001.

24. Byrne B. Structural equation modeling with AMOS: basic concepts, applications, and programming. USA: Routledge; 2010.

25. Ullman JB. Structural equation modeling: reviewing the basics and moving forward. J Pers Assess. 2006;87:35-50.

26. $\mathrm{Hu} \mathrm{L}$, Bentler M. Fit indices in covariance structure modeling: sensitivity to underparameterized model misspecification. Psychological. 1998; 3:424-453.

27. Navarro E, Limonero JT, Maté J, Gómez-Romero MJ. Necesidades de comunicación e información en el paciente oncológico superviviente. Psicooncologia. 2010;7:127-141.

28. Guzmán MA, Ramos CL, Castañeda SO, López-del Castillo SD, Gómez AA. Satisfacción de los usuarios de una unidad de medicina familiar. Rev Med Inst Mex Seguro Soc. 2006;44:39-45. 